\title{
The application of SWOT ${ }^{1}$ model to compile appropriate strategies for projects risk management in: Fooladtechnic International Company
}

\author{
Azadeh Eshaghi $^{1}$, Safoura Mousavi ${ }^{2}$, Amir Eshaghi $^{1}$ \\ ${ }^{1}$ Master of Industrial Engineering, Najaf-Abad Branch Islamic Azad University, Esfahan, Esfahan, Iran \\ ${ }^{2}$ Master of Industrial Engineering, Arak Branch Islamic Azad University, Esfahan, Esfahan, Iran \\ Email address: \\ azadeh_eshaghi3@yahoo.com (Azadeh E.), sogol.moosavi@yahoo.com (Safoura M.), ameshaghi@yahoo.com (Amir E.)
}

\section{To cite this article:}

Azadeh Eshaghi, Safoura Mousavi, Amir Eshaghi. The Application of SWOT Model to Compile Appropriate Strategies for Projects Risk Management in: Fooladtechnic International Company. Science Journal of Business and Management. Special Issue: Business Analytics and Management. Vol. 3, No. 1-2, 2015, pp. 26-34. doi: 10.11648/j.sjbm.s.2015030102.13

\begin{abstract}
In the present modern world almost all the industrial and developmental activities are defined in the framework of large and small projects and executed by relative organizations. These projects, due to their unique and complex nature, as well as instability and constant changes in underlying conditions, are inevitably confronted with some challenges and opportunities. These challenges and opportunities, so called Risks, should be managed in order to achieve successfully project purposes. Therefore, the effective execution of risk management in various organizations requires selecting the appropriate risk strategy for the project during the life cycle of the project management. Because the absence of an appropriate strategy in this case results in project failure to achieve predetermined purposes. The aim of doing the present study is to utilize the SWOT model for compiling the appropriate project risk strategy such that by the definition of related strategies to 17 different areas of the project management, in accordance to the $\mathrm{cpm} 3$ model, be able to recognize the strength, weakness, opportunity and threat related to each of these functional fields. Furthermore, in order to highlight the usefulness of the model for project's managers and experts we implement the model to the Arfa Steel project of Fooladtechnic International Company.
\end{abstract}

Keywords: Strategic Management, SWOT Model, Risk Management

\section{Introduction}

Projects are inevitably confronted with some challenges and opportunities during their life time. These challenges and opportunities, so called risks, could be classified in the style of internal and external environment risks of the project. Project internal environment includes internal strength and weaknesses and external environment includes the opportunities and threats that the project is faced with. In fact, identification of the project internal and external environment, in line with the strategic program, is a necessity for correct decision making and strategic planning for the project risk. This is the responsibility of the steering committee members, strategic committee, executive vice chancellor, planning deputy, technical deputy, project manager, commercial manager, engineering manager, project risk manager, senior experts and project experts, various

${ }^{1}$ Strenght 6 Weakness ‘ Opportunities Threats technical groups (including the process groups, general plan, building, automation, fluids, etc.). These experts, after identifying the appropriate strategy for the project risk management, will determine the purposes and specify some of the project procedures and policies. This action is caused that project managers adapt a coordinated and integrated approach against the environmental opportunities and threats facing the project and achieve aims related to the project in an appropriate manner.

So far, several models have been recognized for determining a company strategies that each of them contains its own concept and insight and follow special techniques and guidelines. Matrix SWOT approach has been considered as one of the most common ways of determining the strategy. This approach, as determines company's internal and external environment, could also be used for a project to develop project risk strategy based on the internal and external environment of the project. To do this, for this reason at first the project weaknesses, strengths, 
opportunities and threats are determined.

Despite the actions that been done so far, it does not seem that any research has been performed in the field of compiling appropriate strategies for projects risk management by SWOT. Thus the purpose of this article is the application of SWOT model to compile appropriate strategies for engineering projects risk management in Fooladtechnic International Company.

In this research, after recognizing the project risks and prioritizing them based on the probability and the effects of their time and cost in the framework of five Likert scale , high priority risks were identified by Pertmaster Software. Then after classifying them in the strength, weakness, opportunity and threat format, the appropriate risk strategies were identified by the SWOT Matrix. To prioritize and evaluate risk strategies, it is possible to use quantitative strategic planning matrix of QSPM. In this article the application of this approach has been investigated by case study in Fooladtechnic Company.

\section{Theoretical Basics or Research Background}

Strategic management is the process of ensuring the organization to gain benefits from the application of appropriate strategies. Based on this statement, an appropriate strategy is defined in accordance to the requirements of an organization at a given time. Strategic management process includes six continuous and consecutive steps:

1. Environmental analysis

2. Organizational orientation establishment

3. Goal setting

4. Determination and formulation of the strategies

5. Preparation and execution of the strategies

6. Control of the strategies

Strategic planning is a systematic process which includes environmental (internal-external) investigation, compile of strategy, strategy execution, evaluation and control (Mosallaii, 2006).

SWOT analysis, which is by far the most popular, can serve a dual function: it can be used for both internal and external environment scanning (Kheng and Munro, 1999; Lerner, 1999) organization's internal and external environment with the aim of identifying its internal strengths in order to take advantage of its external opportunities and avoid its external threats, its weaknesses. This technique is credited to Albert Humphrey, who led a research project at Stanford University in the 1960s and 1970s using data from the Fortune 500 companies. As a strategic planning tool, the SWOT Analysis is used to evaluate the strengths, weaknesses, opportunities, and threats involved in a project or in a business venture or in any other situation of an organization requiring a decision in pursuit of an objective. It involves monitoring the marketing environment internal and external to the organization or individual.
SWOT analysis is not a new idea in the business practice. This model originated from the Harvard Business School (Delahaye, 2000), Also The SWOT technique is one of the most important tools in strategy compiling process by which information is compared. Basically SWOT is a strategic planning tool. (Haacke, 2001).

During the process of strategic planning, the SWOT analysis is neither the first nor the last step. The first step in the strategic planning process should be a thorough analysis of the organization's mission or vision statements. These statements should serve as a foundation of all planning activities. If the organization does not have a mission or vision statement, the development of such a statement should precede any further plan development activities. In very broad terms, for any organization, overall objectives or missions have to be defined, then internal resources need to be assessed and relevant parts of external environment need to be analyzed before conducting a SWOT analysis and planning steps (Schraeder, 2002).

Robinson (2003) suggested key steps to conduct a SWOT analysis: firstly, brainstorm lists of strengths, weaknesses, opportunities, and threats; secondly, arrange lists of ideas with each category and reduce them to the top five to ten ideas per category; thirdly, review each category separately and discuss each of these ideas and the potential implications to the organization; and fourthly, look at the internal strengths and weaknesses of the organization and see how they relate to the opportunities and threats to the organization; and finally, analyze the received information to determine whether there is both a strength of the organization and an opportunity in the external environment: representing a potential area for growth, or there is both a weakness of the organization and threat in the external environment: representing an area for improvement. These suggested steps are more entrepreneur oriented, but most universities are also predominantly market-oriented; consequently the procedure described can be followed without major modifications. and SWOT is considered as a conceptual framework for systemic analysis (Noori,Abbaspour,Maghsoudlookamali, 2006).

Nowadays SWOT is used by strategy designers and assessors as a modern tool for analyzing the performances and gap status (Nilsson, 2004). From this model perspective, an appropriate strategy can maximize the strengths and opportunities and minimize the weaknesses and threats as much as possible.

There are two matrices in SWOT method for evaluating internal and external factors. Strategic planners by using evaluation matrix for external factors can evaluate the economic, social, cultural, ecological, environmental, and political factors and yet by using internal evaluation matrix can identify and evaluate the relationships between different subjects and provide solutions for them (David, 2012).

In fact,The SWOT matrix is very useful for generating a series of alternatives for a company or business unit based on particular combinations of the four sets of strategic factors. The SWOT matrix illustrates how the external opportunities and threats facing a firm can be matched with its internal 
strengths and weaknesses to result in four sets of possible strategic alternatives. It enables mangers to create various kinds of growth and retrenchment strategies. The SWOT matrix includes:

1. SO strategies focus on how to use strengths of a business to take advantage of opportunities.

2. ST strategies attempt to utilize the strengths of a company to avoid threats.

3. WO strategies aim to eliminate weaknesses to open new opportunities.

4. WT strategies are basically defensive and mainly act to minimize weaknesses and avoid threats.

\section{Methodology}

In fact, strategy is the way of reaching the target. Strategic planning is one of the success requirements in all organizations particularly project-based organizations which continuous sequentially and in the form of cascade from the highest level to the executive levels. Strategic levels include organization level, portfolio levels of the organization projects, plans and projects level.

Strategy in the project level has starting and ending points.
Ending point is where:

1. The target is achieved.

2. The target changes.

3. The strategy does not have the required efficiency to reach the target.

A strategic manager should pay attention to both planning and control, because a non- manager is the one who tries to control the activities without planning. Therefore strategic management process is defined as the statement below: "strategic management is the art and knowledge of formulation, execution, and evaluation of the multidimensional decisions - with emphasize on the integration of factors such as management, marketing, finance, production or services, research, development, information systems, etc. - to reach the organization targets."

The aim of this study is recognition, definition, planning, execution, control and monitoring the project risk strategic planning.

As we can seen in figure 1 Strategic program compiling is done. At first, we identify the vision,mission and values,second with EEE and IEF matrix prepare SWOT matrix ,next by QSPM matrix we prioritize strateges,then we implement and control and monitor strategics.

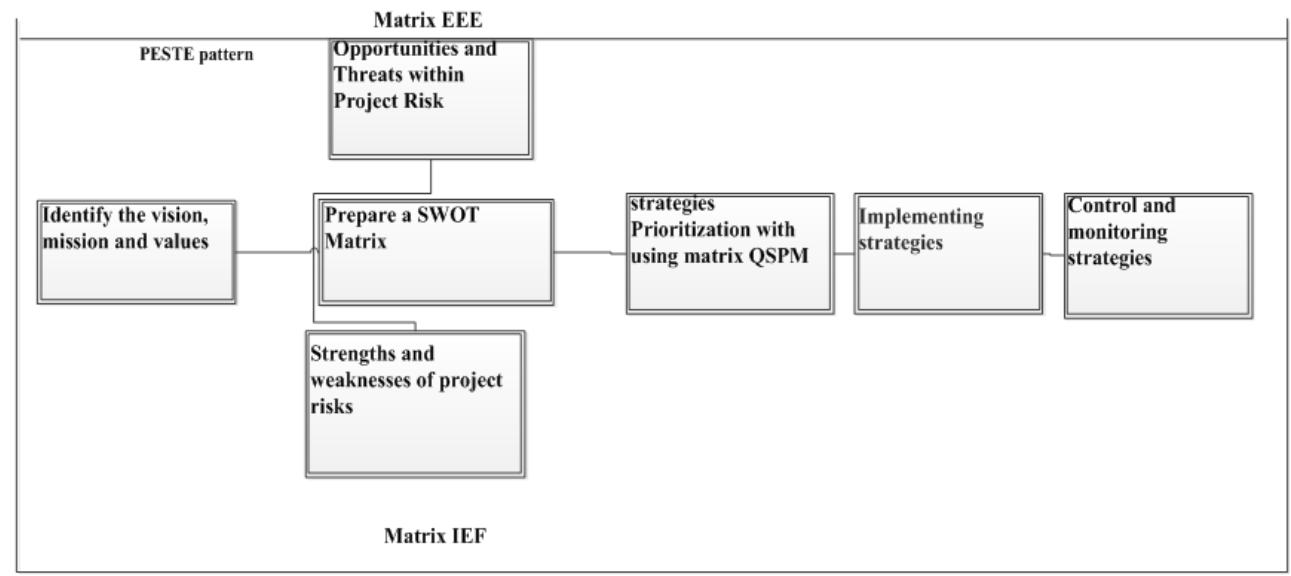

Strategic planning Codification IN project

Figure 1. Strategic program compiling.

\subsection{Formulating the Project Risk Management Strategy}

The purpose of formulating project risk management strategy is determination of the main strategies and strategic orientation of the project risk management.

At first, the steering committee members, strategic committee, executive vice chancellor, planning deputy, technical deputy, commercial manager, Procurement Manager, project manager, engineering manager, project risk manager, senior experts and project experts, various technical groups (including the process groups, general plan, building, automation, fluids, etc.) discussed the issues about management of project risks by using PMBOK model.

According to PMBOK International Standard, risk management process includes the steps bellow:

1. Risk Management Planning

2. Risk Identification
3. Risk Qualification

4. Risk Quantification

5. Risk Response Planning

6. Risk Monitoring and control for probability reduction and also deviation rate reduction in the projects qualitative and quantitative targets.

\subsubsection{Risk Planning}

In this step all risk inputs are being identified. These inputs include:

\section{Providing project historical records}

Economic conditions (exchange rate, interest rate, per capita economic, etc.) organizational issues, risk management outputs, Patterns have been found, previous similar projects planning outputs (monthly reports, technical documents and records)

Project Planning Outputs 
Project Charter, project statement, work breakdown structure, network diagram, estimates, human resource management program, communication management plan to inform all stakeholders about the form and quality of the project communication management, procurement management plan (including supply program + an explanation about the contract or purchase + providers evaluation).

1. Stakeholders information (including project sponsor, organization manager, project manager, project team, team members heads, marketing, sell, quality control departments, employer, consumers, supplier, etc. )

2. Procedures, policies, and risk management organizational patterns.

3. Project limitations (cost, time, performance, quality, employer, customer and stakeholders satisfaction, risk threshold)

4. Hypothesis

5. Risk tolerance areas: corresponding to each constraint.

\subsubsection{Risk Identification}

For identify the risks we help 11 cases that is brought in follow, then we bring their in Table 1.

1. Input distribution between risk management team

2. Input investigation between project team

3. List preparation of potential risks

4. Preparation of probability scale table and risk occurrence effect

5. Preparation of probability matrix and effect

6. Preparation of risk score interval table (threshold table)

7. Preparation of dependency chart form

8. Reviewing risk identification meetings (brain storm)

9. Risk identification

10. Risk classification

11. Preparation of cause and effect risks chart

Table 1. Examples of identified risks and opportunities

Risks and opportunities identified
Poor weather and exhausting work
Unavailability of necessary infrastructure facilities like water, electricity
and other materials timely to start
Unforeseen geological problems and unknown factors Underground
Increase Inflation
Fluctuations Rate of exchange
Exclusive opportunity to develop the domestic market share among
excisting competitors
Opportunities for political communication project managers
Discrepancies in contract documents or explanations inadequate and
incomplete or conflicting interpretations of contract terms
Lack of research and development projects in the company
Expertise and knowledge Engineering Manufacturers and suppliers of
goods

\subsubsection{Risk Qualitative and Quantitative Analysis}

Since the number of identified and classified risks are too high we categorized them. For this reason, the probability, cost impact, and time effect for each of the project risks were obtained with the comments of experts in the form of Likert (5 scale) that brought in Table 2 . Then by using the Pertmaster software we entered all risks and effect of their time and cost. then obtained high priority risks.(figure 1)

Table 2. Probability and Effect Risk of cost and time.

\begin{tabular}{llll}
\hline Likert (5-sclae) & & & \\
\hline Very low & low & middle & high \\
\hline Risks and opportunities & Probability (Likert) & Cost effectiveness (Likert) & Effect of time (Likert) \\
\hline
\end{tabular}

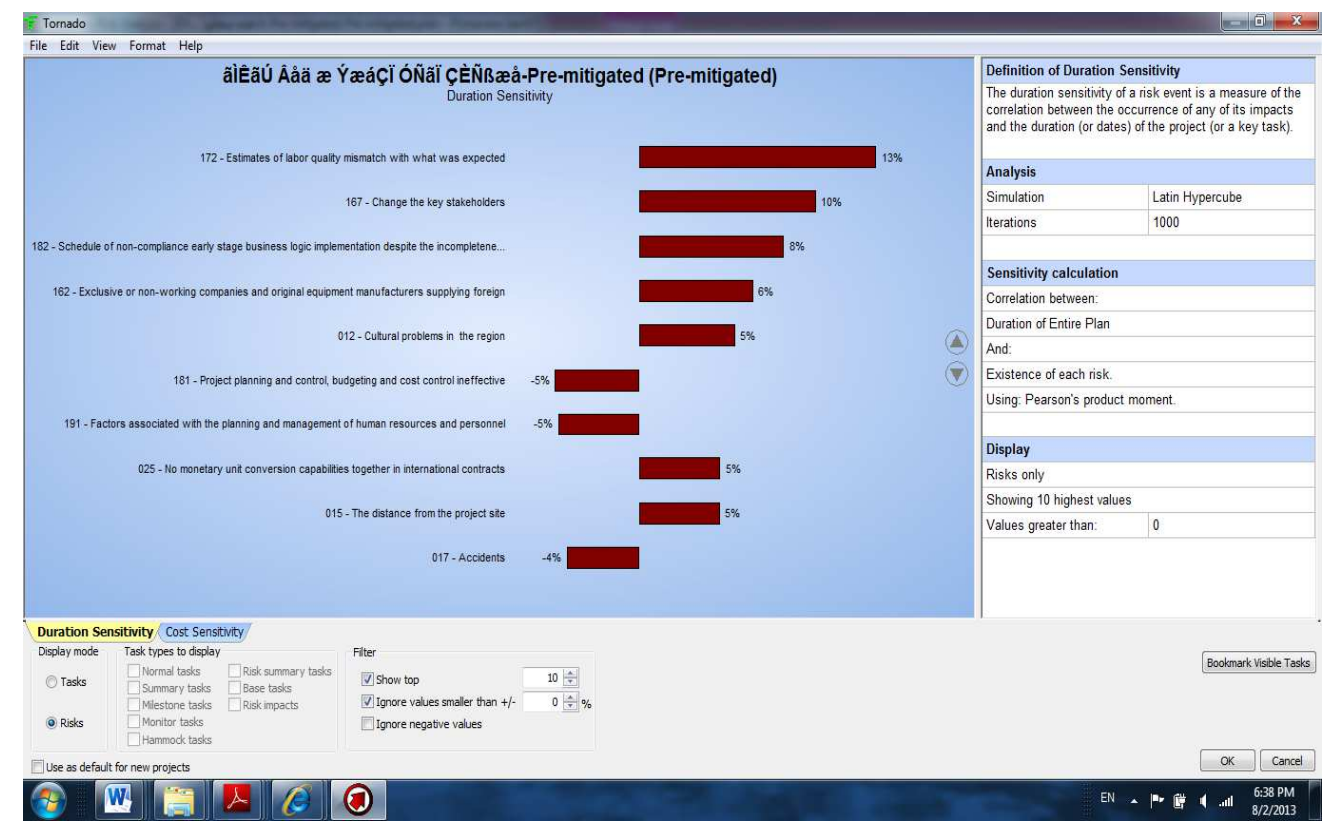

Graph 1. Tornado chart for risk prioritization. 


\subsection{Project Risks Classification by Following Models}

Internal factors: CPM3 maturity model or project CSFs, PEM and EFQM

External factors: PESTLE analysis (including political, economic, social, technological, legal, environmental settings) or new high porter analysis (including: existing competitors, rivals bargaining power, supplier's bargaining, arrival of new competitors, alternative products and government).

By using two tables of projects internal and external factors and putting the score of each table on one dimension of the matrix, IE internal and external factors were identified as follows:

\begin{tabular}{|c|c|c|c|c|c|}
\hline & & perc & t internal & & \\
\hline & & & & & 0 \\
\hline & 100 & Development & Development & Stability & \\
\hline percent external factors & & Development & Stability & Reduction & \\
\hline & 0 & Stability & Reduction & Reduction & \\
\hline
\end{tabular}

Figure 2. Project main strategies.

Developmental strategy for our project was selected based on this evaluation. Of course this should be done continuously and review will be necessary if targets or conditions are changed. .(Figure 3)

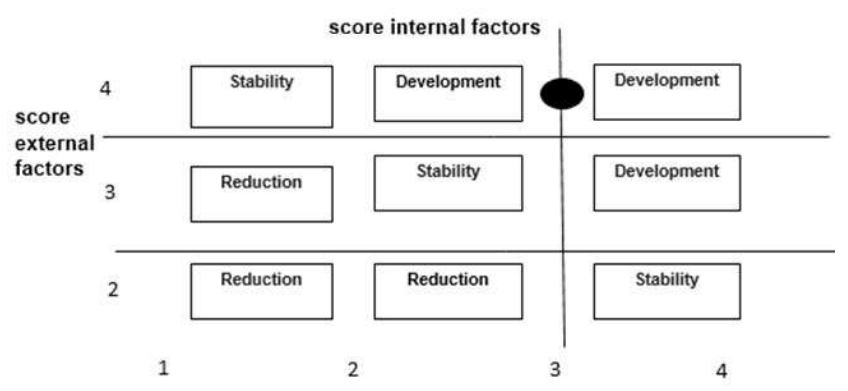

Figure 3. Evaluation matrix for internal and external factors.

\subsection{Implementation Steps of SWOT Analysis for Project Risk Management}

After formulating project risk macro-strategies for Sarmad Abarkooh Steel and Iron Complex (Arfa), strategic options should be determined and classified in framework the for strengths, weaknesses, opportunities, and threats.

We compare internal strengths with the external opportunities and write the result in the related cell in SO strategies group.

We compare internal weaknesses with the external opportunities and write the result in the WO strategies group.

We compare internal strengths with the external threats and write the result in the ST strategies group.

We compare internal weaknesses with the external threats and write the result in the WT strategies group.

SWOT matrix has brought in Table 1.

Table 3. Matrix (SWOT).

\begin{tabular}{lll}
\hline Ws To & S List of the strengths & W List of the weaknesses \\
\hline O list of The opportunites & $\begin{array}{l}\text { Strategy SO with Taking advantage of the strengths attempting } \\
\text { to exploit the opportunities }\end{array}$ & $\begin{array}{l}\text { WO Strategy with Taking advantage of the opportunities } \\
\text { attempting to destroying the weaknesse }\end{array}$ \\
T list of The Threats & ST Strategy Use your strengths to avoid threats & WT Strategy Minimize weaknesses and avoid threats \\
\hline
\end{tabular}

\subsection{Evaluation and Prioritization of Strategic Options by Using Quantitative Strategic Planning Matrix}

After determination of project risk strategy options, main operational strategies of the project should be specified from options. To do this, QSPM matrix is used by which the strategies could be prioritized.

From theoretical perspective, it is possible to specify relative attractiveness of various strategies by using quantitative strategic planning matrix.

\subsubsection{Providing Steps of Quantitative Strategic Planning Matrix}

1. Major external opportunities and threats and also major internal strengths and weaknesses are written in the right column of the quantitative strategic planning matrix (at least 10 very important external factors and 10 very important internal factors).

2. Every internal or external factor which influences the organization success will receive weight or coefficient. These coefficients are written in a column in the left hand side of each internal or external factor.

3. Strategies that the organization should execute are determined and written in the above row of the quantitative strategic planning matrix.

4. Attractiveness scores (a number which shows the attractiveness of each strategy in a set of strategies) are determined. Attractiveness scores are: 1= not attractive, $2=$ relatively attractive, $3=$ reasonably attractive, $4=$ very attractive.

5. Sum of the attractiveness scores is calculated, which means the sum product of the coefficient (second step) in attractiveness scores of (forth step). The total of attractiveness scores presents the relative attractiveness of each strategy which is obtained by only considering the effect of related internal and external factors.

6. Sum of the attractiveness scores is calculated. The sum of attractiveness scores of each column in the quantitative strategic planning matrix shows that which strategy has the most attractiveness in each set.

Note: The major differences between sums of the attractiveness scores in each strategy set reveals the 
sufficiency of a strategy than others.

Table 4. Quantitative strategic planning matrix (QSPM).

\begin{tabular}{|c|c|c|c|c|c|c|c|}
\hline & \multirow{3}{*}{$\begin{array}{l}\text { Importance } \\
\text { Coefficient }\end{array}$} & \multicolumn{6}{|c|}{ Various strategies that can be implemented } \\
\hline & & \multicolumn{2}{|l|}{ Strategy } & \multicolumn{2}{|l|}{ Strategy } & \multicolumn{2}{|l|}{ Strategy } \\
\hline & & $\begin{array}{l}\text { Attractiveness } \\
\text { score }\end{array}$ & Sum of score & $\begin{array}{l}\text { Attractiven } \\
\text { ess score }\end{array}$ & $\begin{array}{l}\text { Sum of } \\
\text { score }\end{array}$ & $\begin{array}{l}\text { Attractiveness } \\
\text { score }\end{array}$ & Sum of score \\
\hline The main external factors & & & & & & & \\
\hline Political Economic & & & & & & & \\
\hline $\begin{array}{l}\text { Sum of score of external } \\
\text { factors }\end{array}$ & 1 & & & & & & \\
\hline The main interernal factor & & & & & & & \\
\hline Management Marketing & & & & & & & \\
\hline $\begin{array}{l}\text { Sum of score of internal } \\
\text { factors }\end{array}$ & 1 & & & & & & \\
\hline Total Score of Strategy & 2 & & $0-8$ & & $0-8$ & & $0-8$ \\
\hline
\end{tabular}

Selection of attractive strategies

By considering mission, internal and external factors of organization or business, the potential strategy for different levels which has been identified and using an evaluation matrix, the suitable strategy for different levels is selected. The most attractive strategies

According to previous worksheets and QSPM matrix in specific, selected strategies of various levels (the best strategies among the existing options - selected strategies for execution) for organization or business are written in a table4 .

The most attracted strategy:

Table 5. Attractive strategies.

\begin{tabular}{llll}
\hline Row & $\begin{array}{l}\text { The best strategy is } \\
\text { applicable in different } \\
\text { levels of your company }\end{array}$ & $\begin{array}{l}\text { The final score of the } \\
\text { attractiveness of each } \\
\text { strategy }\end{array}$ & $\begin{array}{l}\text { Priority any } \\
\text { strategy }\end{array}$ \\
\hline
\end{tabular}

According to the results of QSPM matrix, selected strategies of various levels for organization are listed in the following table 5 .

\subsection{Strategy Executive Plan Preparation}

The main authorities for compiled strategy should provide the Executive program in framwork of project risk strategy execution program for each of the confirmed strategies in the related area.This program reveals the project must What do the programs taken in order to Realization of project risk strategy. where in Describe the titles like strategy title, execution authorities,Acceptable limits Reception , description of implementation plan, etc. is specified.

Note: In preparation of these programs, requirements for macro targets and strategies should be considered.

Table 6. Processes of strategy executive program.

\begin{tabular}{|c|c|c|c|c|c|}
\hline Row & Process & Scope of Work(sub-process) & Title relevant document & Relevant document & Schedules \\
\hline \multirow{9}{*}{1} & \multirow{9}{*}{$\begin{array}{l}\text { Develop } \\
\text { strategies } \\
\text { for project } \\
\text { risks }\end{array}$} & Codification of project objectives & justify Business for project & Executive plan & $\begin{array}{l}\text { At the beginning of the } \\
\text { project, after continuous } \\
\text { monitoring }\end{array}$ \\
\hline & & Project Risk Planning & $\begin{array}{l}\text { Explain the purpose of } \\
\text { identifying risks }\end{array}$ & $\begin{array}{l}\text { Project Manager and } \\
\text { Risk Manager }\end{array}$ & $\begin{array}{l}\text { After identifying the } \\
\text { goals of the project }\end{array}$ \\
\hline & & Identification of Risks Project & $\begin{array}{l}\text { Risk identification forms and } \\
\text { Check lists }\end{array}$ & $\begin{array}{l}\text { Project Manager and } \\
\text { Risk Manager / Project } \\
\text { Expert }\end{array}$ & $\begin{array}{l}\text { During the project life } \\
\text { cycle once a month }\end{array}$ \\
\hline & & $\begin{array}{l}\text { Qualitative and quantitative risk } \\
\text { analysis }\end{array}$ & $\begin{array}{l}\text { Check List likelihood and } \\
\text { impact of risks, costs and time } \\
\text { based on a Likert }\end{array}$ & $\begin{array}{l}\text { Project Manager and } \\
\text { Risk Manager / Project } \\
\text { Expert }\end{array}$ & $\begin{array}{l}\text { During the project life } \\
\text { cycle once a month }\end{array}$ \\
\hline & & $\begin{array}{l}\text { Prioritize risks with high priority } \\
\text { and classify them }\end{array}$ & pertmaster software & Risk Manager & $\begin{array}{l}\text { During the project life } \\
\text { cycle once a month }\end{array}$ \\
\hline & & $\begin{array}{l}\text { Formulating strategies for project } \\
\text { risks }\end{array}$ & $\begin{array}{l}\text { form for input and output } \\
\text { matrix for Project Risk }\end{array}$ & $\begin{array}{l}\text { Executive Director/ } \\
\text { Project Manager and } \\
\text { Risk Manager }\end{array}$ & After obtaining the risks \\
\hline & & SWOT Analysis & $\begin{array}{l}\text { Performance Form for swot } \\
\text { analysis and determine project } \\
\text { risk strategy }\end{array}$ & Project Manager & At least once a 6 months \\
\hline & & $\begin{array}{l}\text { Determining Options for Project } \\
\text { Risk Strategic }\end{array}$ & $\begin{array}{l}\text { QSPM analysis Form and } \\
\text { determining appropriate risk } \\
\text { strategy }\end{array}$ & Project Manager & At least once a 6 months \\
\hline & & Wrap-up strategies & Project Risk Strategies form & Project Manager & At least once a 6 months \\
\hline
\end{tabular}

\subsection{Project Risk Strategy Execution}

The execution of strategy is performed by using project balanced scorecard model"PMBSC". Following the determination of strategy, it is classified in the framwork 4.dimentional of balanced scorecard. Then after designation 
of purposes related to project risk strategies, related indicators are specified. .(Table 7)

Table 7. Execution process of project risk strategy.

\begin{tabular}{llllll}
\hline Row & Process & Description of work sub- Process & Title of relevant document & Relevant document & Schedules \\
\hline 2 & $\begin{array}{l}\text { Implementation OF } \\
\text { project risk strategy }\end{array}$ & $\begin{array}{l}\text { Review forms, plans and activities } \\
\text { undertaken to implement the strategy }\end{array}$ & $\begin{array}{l}\text { Application form for implement the } \\
\text { project risk strategy based on the } \\
\text { balanced scorecard model }\end{array}$ & $\begin{array}{l}\text { Strategic leaders / } \\
\text { project managers }\end{array}$ & $\begin{array}{l}\text { At least once } \\
6 \text { months }\end{array}$ \\
\hline
\end{tabular}

\subsection{Supervision and Control of Project Risk Strategies}

Table 8. Supervision and control processes for project risk strategies.

\begin{tabular}{|c|c|c|c|c|c|}
\hline Row & Process & Description of work sub- Process & Title of relevant document & Relevant document & Schedules \\
\hline \multirow{3}{*}{3} & \multirow{3}{*}{$\begin{array}{l}\text { Control of } \\
\text { Project } \\
\text { Strategies }\end{array}$} & $\begin{array}{l}\text { Preparation Question and Follow-up } \\
\text { survey form realization of project risk } \\
\text { strategies }\end{array}$ & $\begin{array}{l}\text { Survey form realization of } \\
\text { project risk strategies }\end{array}$ & $\begin{array}{l}\text { Project } \\
\text { authorities/strategies } \\
\text { authorities }\end{array}$ & At least once 6 months \\
\hline & & $\begin{array}{l}\text { Comparison of Strategies Project Risk } \\
\text { Using to determine index and determine } \\
\text { necessary actions }\end{array}$ & $\begin{array}{l}\text { Control Form for project } \\
\text { strategies }\end{array}$ & $\begin{array}{l}\text { Project } \\
\text { authorities/strategies } \\
\text { authorities }\end{array}$ & At least once 6 months \\
\hline & & Perform corrective actions has been taken & $\begin{array}{l}\text { Control Form for project } \\
\text { strategies }\end{array}$ & Region Authorities & Based on the analysis of \\
\hline
\end{tabular}

This process is performed through comparing the performance of project risk strategy with planed risk strategy and controlling the project risk strategy changes.

Continuing these steps, by initializing the quantitative targets are specified the indicator limitations in order to control the risk strategies in every functional area. The accessibility to targets and strategies is controlled and In case of contradiction the appropriate corrective actions are determined. .(Table 8)

\section{Data Analysis}

Finally, we brought a risks in BSC framework in tabale 9

Table 9. SWOT matrix for project risks.

\begin{tabular}{|c|c|}
\hline \multicolumn{2}{|c|}{ Strengths, Weaknesses, Opportunities, Threats } \\
\hline \multirow{11}{*}{ Strengths } & 1-accurate decision the Project managers in line with the precautionary measures1 \\
\hline & 2-The amount of quality information from the project manager and the project management to audit teams \\
\hline & 3-the opportunity to apply modern software and hardware infrastructure and suitable data base \\
\hline & 4-Company's ability to attract and retain experienced and active force \\
\hline & 5-handle multiple projects simultaneously \\
\hline & 6-documentation for the use of positive and negative experiences in implementing projects next \\
\hline & 7-Access to Knowledge Management and High Tech \\
\hline & 8 -ability of company to the formulation of strategic plans \\
\hline & 9-ability of company to the focused management in critical situation \\
\hline & 10-Political Communication Project Managers \\
\hline & 11-the Opportunities for Training the efficient manpower \\
\hline \multirow{9}{*}{ Weaknesses } & 1- worsening economic conditions of company \\
\hline & 2- unrealistic or inaccurate cost estimates \\
\hline & 3- Inaccurate estimates of Project Time \\
\hline & 4- Profit-seeking all of involved people that in the project due to poor organizational culture \\
\hline & 5- Lack of sufficient coordination between staff and managers and project specialists \\
\hline & 6- Lack of commitment of some forces and abandon the project \\
\hline & 7- Lack of method proper implementational And appropriate project control \\
\hline & 8- Lack of research and development projects at company \\
\hline & 9- weak will, weak commitment of all of involved people in the project to complete the project on time \\
\hline \multirow{6}{*}{ Opportunities } & 1- exclusively between competitors and development of domestic market share \\
\hline & 2- Provide timely funding to projects by the employer \\
\hline & 3 - The Executive Power at communication and coordination between all parts of the project (contractors, consultants, employer) \\
\hline & 4- opportunity to become familiar with Certified contractors Within the project \\
\hline & 5- Coordination among departments by the contractor \\
\hline & 6- Engineering expertise and knowledge manufacturers and suppliers of goods \\
\hline \multirow{9}{*}{ Threats } & 1- Rising inflation \\
\hline & 2- Fluctuations in exchange rates \\
\hline & 3- Increase in interest rate \\
\hline & 4- Increase unconventional sanctions \\
\hline & 5- landslides \\
\hline & 6- environmental pollutants \\
\hline & 7- unanticipated geological problems and unknown factors underground \\
\hline & 8- weaknesses errors in the contract documents and therefore the false diagnosis of financial statements \\
\hline & 9 - Lack of management ability and inadequate experience of local contractors \\
\hline
\end{tabular}




\begin{tabular}{l}
\hline Strengths, Weaknesses, Opportunities, Threats \\
\hline 10- poor management and weak supervision in site \\
11- confirmation delay \\
12 - lack of adequacy and ability to leading manufacturers Leading to wide variations in process
\end{tabular}

Selected strategy options by QSPM matrix:

SO: Exclusiveness and development of domestic market share through investment in industrial and civil projects and improvement of project manager's political communication

ST: Environmental protection through upgrading the knowledge and company's project management abilities in accordance with international standards of project management and quality management.

WO: Development of organizational capital through increasing coordination

WT: Integrating targets between project stakeholders through the establishment of an appropriate contract

Due to massive changes in environmental conditions of the project, there always should be a risk strategy revision system. Therefore, project risk strategies have been reviewed in certain time areas. .(table 10)

\section{Discussion and Conclusion}

Investigating the SWOT matrix as factors effecting is the advance of an organization purposes. Preparation of weaknesses and threats that existing in project-driven organizations as internal factor and Opportunities and
Threats as external factor To determine the strategy to achieve organizational goals helps.

One of the best results use of SWOT is this that the projects could By comparing between threats, their weaknesses ,the factors that causing project failure and inability to achieve the targets Separately identify And solutions that can help prevent the failure of the project to apply. It's use for prevent of project failure and gain of some predictions for the projects future

By applying this analysis we want to know whether the project is able to use opportunities and minimize the threats.

Also discovering the organization weaknesses is very important for the investigation of the project internal performance.

With using this tool among other strategic management tools such as balanced scorecard, it is possible the importance of each components of the internal and external environment to be detect.

Application of this technique was evaluated in Steelmaking project of Sarmad Abarkooh (Arfa) in Fooladtechnic International Company to demonstrate the appropriate performance of this project in compare with other projects.

Table 10. Option determination for project risk strategy.

\begin{tabular}{|c|c|c|c|c|}
\hline & So strategy & St strategy & Wo strategy & Wt strategy \\
\hline 1 & $\begin{array}{l}\text { 1- Exclusiveness and } \\
\text { development of domestic } \\
\text { market share through } \\
\text { investment in industrial and } \\
\text { civil projects and improvement } \\
\text { of project manager's political } \\
\text { communication. }\end{array}$ & $\begin{array}{l}\text { 1-improving the cost } \\
\text { structure to mitigate the } \\
\text { effects of fluctuations in } \\
\text { exchange rates, interest } \\
\text { rates and increased } \\
\text { sanctions }\end{array}$ & $\begin{array}{l}\text { 1-improving economic conditions by } \\
\text { providing timely funding of the project } \\
\text { by the employer }\end{array}$ & $\begin{array}{l}\text { 1 Integrating targets between project } \\
\text { stakeholders through the } \\
\text { establishment of an appropriate } \\
\text { contract. }\end{array}$ \\
\hline 2 & $\begin{array}{l}\text { 2- utilizing appropriate } \\
\text { information systems and } \\
\text { appropriate databases }\end{array}$ & $\begin{array}{l}\text { 2-Increase the ability of } \\
\text { management to improve } \\
\text { asset use through } \\
\text { maximizing return on } \\
\text { investment }\end{array}$ & $\begin{array}{l}\text { 2- Development of organizational } \\
\text { capital through increasing coordination }\end{array}$ & $\begin{array}{l}\text { 2-Excellence in optimal } \\
\text { management of contractors, } \\
\text { consultants and suppliers }\end{array}$ \\
\hline 3 & $\begin{array}{l}\text { 3- creating platform a fast, safe } \\
\text { and reliable and integrated } \\
\text { information }\end{array}$ & $\begin{array}{l}\text { 3- Environmental protection } \\
\text { through upgrading the } \\
\text { knowledge and company's } \\
\text { project management } \\
\text { abilities in accordance with } \\
\text { international standards of } \\
\text { project management and } \\
\text { quality management. }\end{array}$ & $\begin{array}{l}\text { 3-the promotion of culture and good } \\
\text { team spirit among employees }\end{array}$ & $\begin{array}{l}\text { 3-The use of contractors and } \\
\text { consultants to help the worsening } \\
\text { economic conditions o } \\
\text { Exclusiveness and development of } \\
\text { domestic market share through } \\
\text { investment in industrial and civil } \\
\text { projects and improvement of project } \\
\text { manager's political communication. } \\
\text { f company }\end{array}$ \\
\hline 4 & $\begin{array}{l}\text { 4- The development of } \\
\text { standards and infrastructure the } \\
\text { hardware and software to } \\
\text { improve the project } \\
\text { management process }\end{array}$ & & $\begin{array}{l}\text { 4-Improving humanresources } \\
\text { management system and more } \\
\text { motivated employees and their } \\
\text { participation in the development of } \\
\text { human capital }\end{array}$ & \\
\hline 5 & $\begin{array}{l}\text { 5-education improvement all } \\
\text { project members to develop } \\
\text { human capital }\end{array}$ & & $\begin{array}{l}\text { 5-Develop and enhancing the capacity } \\
\text { for acquiring and implementing new } \\
\text { projects through evaluating director } \\
\text { reports, market analysis and research } \\
\text { and development plans }\end{array}$ & \\
\hline
\end{tabular}




\section{References}

[1] Ahmed, A. M., Zairi, M., and Almarii, K. S.(2006) SWOT analyze for air china for mance and its experience with quality.

[2] Ahmadi,P., Gholamalizadeh, A., Mohamadsafari, M. (2009). a study comparative investigating environmental in order to compiling strategy For car companies to Direction of their Integrated management.

[3] Chang., Huang,H .,and Chin,W .(2003)Application of a quantification SWOT analytical method

[4] Delahaye, B. L.(2000). Strategic human resource development Milton: John Wiley \&Sons.

[5] Duarte,C. ,Lawrence, P.E., Helms, M., and Anderson,A. (2005).The challenge of the VeneZuela :a swot analaysis.

[6] EFQM(European Foundation for Quality Management).

[7] Fredar,D.(2012).StrategicManagement.(translator Parsaiyan,A and Arabi,A). $1^{\mathrm{ST}}$. Cultural Research Bureau.

[8] Ghafarian,V.and Emadzadeh,M.(2006). Meanings emerging at The concept of strategy. $2^{\text {nd }}$.organization of industrial management.

[9] Haacke, L (2001). Using swot for Project Planning Sessions, PN.3 Hughes. ATourism as sustainable Industry in the Rural Community of Arising.( MSc Thesis). Napier University, West Scotland

[10] Kheng-Hor, K. and N. Munro-Smith (1999). Reader-Friendly Strategic Management: A delightful blend of academic learning and Street-smart practices. Selangor Darul Ehsan: Pelanduk Publications.

[11] Lerner, A. L. (1999). A Strategic Planning Primer for Higher Education.Northridge, viewed8July2006. $<$ http://www.des.calst ate.edu/strategic.html>

[12] Lee,S.F.Bulding balanced scorecard with SWOT analaysis, and implementing "Sun TZU,S The art of businesss Management Strategies" on QFD methology.

[13] Mosallaii,M(2006)."strategic planning Approach towards organization excellence". management journal.NO.39.

[14] Nilsson,M.(2004).Research and advice on strategic environmental assessment Stockholm Environment in Stitute Publications.

[15] Noori,J,Abbaspour,M.,Maghsoudlookamaili,B.(2006). "strategic environmental assessment IN Iran's industrial development policy by using of swot model". Journal of Environmental Sciences and Technology.ISSN 1563-4809.

[16] Project Management Institute Standard Committee, A guide to the Project Management Body of Knowledge , fourth edition, 2008

[17] Piyers,J. and Robinson,R.(2009).Planning and Strategic Management,(translator,Khalilishorini,S). $5^{\mathrm{TH}}$.Yadvare book .pp 307-309.

[18] Robinson, R. (2003). How to conduct a SWOT analysis, ABARIS Consulting Inc., viewed 8 July 2006. $<$ http://www.charityvillage.com/cv/research/rstrat19.html $>$.

[19] Schraeder, M.(2002). A simplified approach to strategic planning: Practical considerations and an illustrated example. Business Process Management, 8(1).pp 8-18. 